\title{
Analisa Kejahatan Penyelundupan Manusia Berdasarkan Smuggling of Migrants Protocol Ditinjau dari Perspektif Perlindungan Pencari Suaka: Studi Kasus Pengungsi Rohingnya
}

\author{
Diajeng Wulan Christianti*
}

\begin{abstract}
Abstrak
Eksodus besar-besaran etnis muslim Rohingya keluar Myanmar kembali terjadi sebagai akibat dilakukannya pembakaran desa, eksekusi, hingga pemerkosaan oleh militer Myanmar di Rakhine. Meskipun mereka harus rela membayar mahal, cara penyelundupan manusia kerap mereka gunakan karena cara formal untuk bisa masuk ke negara lain tidak dimungkinkan. Tindakan penyelundupan manusia adalah tindak pidana dalam Smuggling Protocol di mana negara-negara yang disinggahi pengungsi Rohingya seperti Thailand, Bangladesh, bahkan Indonesia telah menjadi negara pihak. Akibatnya, Pemerintah Thailand dan Bangladesh kerap menangkap pengungsi Rohingya yang masuk ke negaranya bahkan mengusir mereka untuk kembali ke Myanmar. Padahal sebagai pencari suaka yang terancam persekusi, etnis Rohingya dilindungi oleh hukum Hak Asasi Manusia khususnya prinsip non-refoulement. Artikel ini menganalisa dilema antara aturan Smuggling Protokol yang bertujuan mencegah dan menegakan hukum atas terjadinya kejahatan penyelundupan manusia dengan kewajiban memberikan pengaman untuk melindungi hak-hak para pengungsi yang terancam persekusi. Artikel ini berkesimpulan bahwa meskipun Smuggling Protocol mampu untuk memberikan keseimbangan antara penegakan hukum kejahatan perlindungan manusia dan perlindungan pencari suaka, akan tetapi pada akhirnya semua tergantung dari keinginan negara untuk menerapkan Smuggling Protocol tersebut melalui aturan implementasi yang jelas namun proporsional.
\end{abstract}

Kata Kunci: non-refoulement, pencari suaka, penyelundupan manusia, Smuggling protocol, Rohingya.

\section{An Analysis of Smuggling of Migrants under Smuggling Protocol from Asylum Seeker Protection Perspective: Case Study of Rohingya}

\begin{abstract}
Again, thousands of Rohingya flee Myanmar to escape persecution after they saw their homes burned down, their family executed, and also suffered rape and torture by the Myanmar's Military. In order to flee to Thailand or Bangladesh, Rohingyas often resort to using people smugglers and have to pay large amount of money. It is the only option left for desperate Rohingyas to save their lives. Smuggling of Migrants is criminal act under Smuggling Protocol. Thai and Bangladesh authorities (which are state parties to Protocol) often detained the Rohingyas for illegal entrance or expelled them back to Burmese government. The state parties of the Smuggling Protocol are obliged to investigate and prosecute the smugglers as well as to prevent and suppress the crimes. Nevertheless,
\end{abstract}

PADJADJARAN Jurnal IImu Hukum Volume 3 Nomor 3 Tahun 2016 [ISSN 2460-1543] [e-ISSN 2442-9325]

* Dosen Fakultas Hukum Universitas Padjadjaran, Jl. Dipati Ukur No. 35 Bandung, wulanchristianti@gmail.com, S.H. (Universitas Padjadjaran), LL.M. (Geneva Academy of International Humanitarian Law and Human Rights) 
asylum seekers fearing of persecution are protected under international human rights law including the principle of non-refoulement. This paper thus examines whether the Smuggling Protocol can solve the aforementioned dilemma by providing adequate refugee rights safeguards. This paper concludes that whilst the Smuggling Protocol has potential to do such, its application ultimately depends on the will of the State parties to apply the Protocol through proportionate yet clear implementing regulations.

Keywords: asylum seekers, non-refoulement, Rohingya, smuggling of migrants, Smuggling Protocol.

\section{A. Pendahuluan}

Akhir-akhir ini dunia kembali dikejutkan dengan pemberitaan para pengungsi Rohingya yang kembali melakukan eksodus besar-besaran keluar wilayah Myanmar. Penembakan 9 (sembilan) orang polisi Myanmar oleh orang tak dikenal (diduga kelompok Islam Radikal) diduga menjadi pemicu memanasnya situasi di wilayah Rakhine Myanmar. ${ }^{1}$ Pemerintah Myanmar diduga mendiamkan tragedi kemanusiaan ini dan tidak melakukan apa-apa meskipun hal tersebut disangkal oleh Aung San Su Kyi, pemimpin partai terbesar di Myanmar. ${ }^{2}$ Para pengungsi Rohingya membayar mahal kepada jasa penyelundup manusia, yakni sekitar 1.1 juta Kyats (sekitar 850US\$) untuk dapat keluar dari wilayah Myanmar dan pergi ke Thailand. ${ }^{3}$ Meskipun setelah mereka tiba, aparat polisi Thailand kerap menangkap mereka atas tuduhan memasuki wilayah negara secara ilegal. ${ }^{4}$ Ada beberapa hal yang layak disoroti dalam permasalahan pengungsi Rohingya di atas, yakni status mereka sebagai pencari suaka yang terancam persekusi, ${ }^{5}$ pemilihan cara mereka untuk meninggalkan wilayah Myanmar dengan menggunakan jasa penyelundup manusia, serta penangkapan dan pemulangan orang-orang tersebut oleh negara transit atau negara tujuan.

1 Time, "Violence in Burma Has Sent Hundreds of Rohingya Muslims Fleeing to Bangladesh", http://time.com/4574298/burma-myanmar-rohingya-bangladesh-refugees-islamic-militants/, diakses 20 November 2016.

2 UNHCR, "Burma : Study: Rohingya Among World's Most Prosecuted", http://Www.Unhcr.Org/Cgi-Bin/Texis/Vtx/Refdaily?Pass=52fc6fbd5\&ld=5445f0238, diakses 26 November 2016.

3 Ameera, "Menjadi Korban Perdagangan Manusia, 5 Muslim Rohingya kini Malah Dipenjara di Myanmar", https://www.arrahmah.com/news/2016/10/29/Menjadi-Korban-Perdagangan-Manusia-5-MuslimRohingya-Kini-Malah-Dipenjara-Di-Myanmar.html, diakses 26 November 2016.

4 Ibid.

5 "As well as being stateless, Myanmar's Rohingyas are confronted with other forms of persecution, discrimination and exploitation. These include (but are not limited to) forced labour, extortion, restriction on freedom of movement, the absence of residence rights, inequitable marriage regulations and land confiscation. The Rohingya also have limited access to secondary and tertiary education as well as other public services". Dikutip dari United Nations High Commissioner for Refugees (UNHCR), "States of denial A review of UNHCR's response to the protracted situation of stateless Rohingya refugees in Bangladesh", http://www.unhcr.org/enus/research/evalreports/4ee754c19/states-denial-review-unhcrs-response-protracted-situation-statelessrohingya.html, hlm. 7, diakses 26 November 2016. 
Rohingya bukan satu-satunya kelompok pencari suaka yang terancam persekusi. Badan Pengungsi PBB (United Nations High Commissioner for Refugee/ UNHCR) dalam laporan Global Trend 2015 menunjukkan 65,3 juta orang di dunia telah dipaksa meninggalkan negaranya, yang mana 21.3 juta diantaranya adalah pengungsi yang setengah dari jumlah tersebut adalah anak-anak di bawah usia 18 tahun. ${ }^{6}$ Setiap harinya di dunia ini, nyaris 34 ribu orang per hari dipaksa pindah dan bermigrasi dari negaranya akibat konflik bersenjata atau ancaman persekusi. ${ }^{7}$

Berbagai situasi di dunia seperti konflik atau perbedaan pandangan antara rakyat dan pemerintah berdampak pada situasi keamanan di suatu negara yang juga berdampak pada individu-individu yang tinggal di wilayah tersebut. Guna memperoleh penghidupan yang lebih layak dan aman serta keamanan diri, mereka bermigrasi ke negara lain sebagai pengungsi maupun pencari suaka. Sebagai contohnya, perang sipil yang terjadi di Suriah, ${ }^{8}$ Palestina, ${ }^{9}$ termasuk pengusiran kaum Rohingya di Myanmar yang dinyatakan oleh UNHCR sebagai kelompok minoritas yang paling dipersekusi di dunia. ${ }^{10}$ Wilayah Association of South East Asian Nations (ASEAN) misalnya Indonesia, Thailand, dan Malaysia sering dijadikan tempat transit ${ }^{11}$ atau tempat tujuan para pengungsi dan pencari suaka.

Permasalahan pencari suaka seringkali dikaitkan dengan permasalahan kejahatan penyelundupan manusia karena mereka kerap menggunakan jasa penyelundup untuk dapat keluar dari negaranya dan masuk ke negara lain. Berdasarkan hukum internasional, penyelundupan manusia merupakan salah satu bentuk kejahatan transnasional terorganisir dan diatur dalam Pasal 3 (a) Protocol Against The Smuggling of Migrants by Land, Sea, and Air, Supplementing the United Nations Convention Against Transnational Organized Crime 2000 (Smuggling Protocol).

Protokol ini menjelaskan bahwa penyelundupan manusia adalah pengadaan pengangkutan manusia untuk mendapatkan keuntungan masuk secara ilegal ke dalam suatu negara. Penyelundupan manusia merupakan permasalahan serius yang harus ditangani dan perlu mendapat perhatian khusus semua negara. Hal ini dikarenakan penyelundupan manusia merupakan 'perdagangan' berbahaya,

\footnotetext{
UNHCR, “Figures at Glance”, http://www.unhcr.org/figures-at-a-glance.html, diakses 10 November 2016.

Ibid.

8 Sarah Bidinger (et.al.), "Protecting Syrian Refugees: Laws, Policies, and Global Responsibility Sharing”, Boston University Report, 2014, hlm. 1.

9 Andrew Kent, "Evaluating The Palestinians Claimed Right of Return", University of Pennsylvania Journal of International Law, Vol. 34, 2012, hlm. 151.

10 UNHCR, “Burma: Study: Rohingya among World's Most Persecuted," UNHCR Refugee Daily, October 20, 2014, http://www.unhcr.org/cgi-bin/texis/vtx/refdaily?pass=52fc6fbd5\&id=5445f0238, diakses 10 November 2016.

11 Mathew Penelope dan Harley Tristan, "Refugees Protection and Regional Cooperation in Southeast Asia, A Fieldwork Research", Australian National University, March 2014, http://www.mcrg.ac.in/WC 2015/ Reading/D RefugeeProtection.pdf, diakses 20 November 2016.
} 
bukan hanya karena uang yang dikumpulkan hasil penyelundupan ini biasa digunakan untuk tindak pidana misalnya perdagangan narkotika atau senjata, namun penyelundupan merupakan kegiatan yang membahayakan jiwa manusia itu sendiri.

Selain kasus Rohingya, kasus yang paling mencengangkan hati nurani manusia akibat penyelundupan manusia misalnya 58 warga negara Tiongkok yang meninggal karena bersembunyi di truk pengangkut tomat di Pelabuhan Dover Inggris tahun 2000 lalu. ${ }^{12}$ Selain itu, orang-orang yang diselundupkan kerap menderita baik karena mendapatkan penyiksaan atau perkosaan oleh penyelundupnya, atau bahkan mereka mendapatkan perjalanan yang sangat buruk dengan dipenjara di negara tujuan sampai dideportasi kembali ke negara asal. ${ }^{13}$ Para pencari suaka yang menggunakan jasa penyelundup manusia secara serius menuntut hak suaka mereka di suatu negara agar terlepas dari pertanggungjawaban pidana. Terkadang pencari suaka juga menjadi penjahat sebagai dampak pergaulan mereka dengan penyelundup misalnya menjadi pengemis, pedagang obat bius, karena utang mereka kepada penyelundup belum lunas.

Terdapat 2 (dua) aspek yang diperhatikan dalam kaitan kejahatan penyelundupan manusia dengan perlindungan terhadap pencari suaka. Pertama, adalah hak setiap orang yang dijamin dalam Deklarasi Universal Hak Asasi Manusia (DUHAM) untuk mencari suaka ke negara lain karena ancaman/tindakan persekusi dari negaranya ${ }^{14}$ serta hak atas penghidupan yang layak. ${ }^{15}$ Artinya, para pencari suaka memiliki hak yang dilindungi dalam hukum Hak Asasi Manusia (HAM). Terlebih bila negara penerima merupakan negara pihak berbagai instrumen terkait seperti International Covenant on Civil and Political Rights (ICCPR), Convention Relating to the Status of Refugees 1951 (Refugee Convention 1951), atau Convention against Torture and other Cruel Inhuman Treatment or Punishment 1984 (CAT).

Kemudian aspek kedua, masyarakat internasional menyepakati bahwa penyelundupan manusia merupakan salah satu bentuk kejahatan transnasional

Claire Brolan, "An Analysis of the Human Smuggling Trade and the Protocol Against the Smuggling of Migrants by Land, Air and Sea (2000) from a Refugee Protection Perspective", International Journal of Refugee Law, Vol. 14 No. 4, October 2002, http://oppenheimer.mcgill.ca/IMG/pdf/Brolan.pdf diakses 10 November 2016, hlm. 578.

13 Migrant Smuggling and Trafficking in Persons', Canadian Refugee Council, 20 Feb. 2000, http://ccrweb.ca/sites/ccrweb.ca/files/static-files/traffick.html, diakses 10 November 2016.

14 Pasal 14 Deklarasi Universal Hak Asasi Manusia (DUHAM) menyatakan bahwa:

1. Everyone has the right to seek and to enjoy in other countries asylum from persecution.

2. This right may not be invoked in the case of prosecutions genuinely arising from non-political crimes or from acts contrary to the purposes and principles of the United Nations.

15 Pasal 25 (1) DUHAM: "Everyone has the right to a standard of living adequate for the health and well-being of himself and of his family, including food, clothing, housing and medical care and necessary social services, and the right to security in the event of unemployment, sickness, disability, widowhood" 
yang harus dicegah dan diberantas di mana penegakan hukum terhadap para pelaku merupakan hal yang krusial. $^{16}$

Definisi penyelundupan manusia dalam Pasal 3 Protokol di atas tidak secara jelas mengecualikan pencari suaka sebagai bentuk penyelundupan manusia. Pasal tersebut secara luas menggunakan istilah 'person' dalam menjabarkan 'illegal entry' sementara semua pencari suaka rata-rata akibat dari konflik bersenjata yang berlarut-larut dinegaranya tidak memiliki dokumen memadai untuk masuk ke suatu negara. Orang yang diselundupkan dalam konteks kejahatan ini berbedabeda baik dari latar belakang ekonomi, pendidikan, termasuk golongan lemah (vulnerable groups) yang mencakup wanita, anak, dan pencari suaka serta pengungsi. Apabila melihat pengaturan pada Pasal 5 Smuggling Protocol di atas, orang yang diselundupkan tidak dapat dimintai pertanggungjawaban pidana hanya berdasarkan fakta bahwa mereka diselundupkan berdasarkan Pasal 6. Namun dalam praktiknya, seringkali mereka yang diselundupkan berubah menjadi penyelundup dalam perjalanan menuju negara tujuan. Dengan demikian, perlu dianalisa lebih lanjut mengenai perlindungan para pencari suaka yang menggunakan jasa penyelundup agar pengkriminalisasian dari kejahatan ini tidak bertentangan dengan perlindungan internasional yang dijaminkan kepada para pencari suaka berdasarkan hukum internasional.

Kasus Rohingya memperlihatkan pengaturan kejahatan penyelundupan manusia baik di tingkat internasional hingga tingkat nasional berpotensi memberikan dampak (atau kerugian) terhadap perlindungan internasional yang seharusnya dijaminkan kepada para pencari suaka tersebut. Di satu sisi, penyelundupan dapat memberikan jalan bagi para pencari suaka terbebas dari ancaman persekusi dari negaranya sendiri dan mendapatkan suaka dari negara lain. Namun di sisi lain, penyelundupan manusia dapat membuat pencari suaka semakin lemah dan berpotensi terjadinya pelanggaran prinsip non-refoulement ${ }^{17}$ jika orang yang diselundupkan diintersepsi dan dipulangkan segera ke negara asal dimana ia berpotensi dipersekusi.

\section{B. Pembahasan}

1. Perlindungan Pencari Suaka yang Terancam Persekusi

a. Sumber Hukum Internasional tentang Perlindungan Pencari Suaka

DUHAM, sebagai deklarasi umum hak asasi manusia memberikan hak kebebasan setiap orang untuk meninggalkan setiap negara, termasuk negaranya sendiri dan

16 Pasal 6 Protocol against the Smuggling of Migrants by Land, Sea and Air, Supplementing the United Nations Convention against Transnational Organized Crime 2000 (Smuggling Protocol).

17 Pasal 33(1) Refugee Convention 1951menyatakan bahwa:

"No Contracting State shall expel or return ('refouler') a refugee in any manner whatsoever to the frontiers of territories where his life or freedom would be threatened on account of his race, religion, nationality, membership of a particular social group or political opinion." 
untuk kembali ke negaranya. Sebagaimana dinyatakan Pasal 13 ayat (2) DUHAM: "Everyone has the right to leave any country, including his own, and to return to his country". Selain itu, DUHAM juga memberikan hak untuk mencari suaka ke negara manapun. Pencarian suaka tersebut harus dilandasi dengan alasan pencarian suaka dari ancaman hukuman, kecuali ancaman hukuman yang muncul dari tindak pidana non-politik (non-political crimes) atau tindak pidana yang bertentangan dengan tujuan dan prinsip-prinsip dalam Piagam Perserikatan Bangsa-Bangsa (Piagam PBB). ${ }^{18}$ Hak yang diatur oleh DUHAM kemudian ditegaskan kembali dalam salah satu Kovenan utama HAM yakni ICCPR. Pasal 12 ayat (2) ICCPR menegaskan kebebasan untuk meninggalkan setiap negara. Namun hak di atas dapat dibatasi dengan berdasarkan hukum, perlindungan keamanan nasional, ketertiban umum, ke-sehatan publik, moral, ataupun hak dan kebebasan individu lainnya dan konsisten dengan hak-hak yang diatur dalam ICCPR. Hal tersebut dinyatakan dalam Pasal 12 ayat (3) ICCPR. ${ }^{19}$

Selain itu, hukum internasional juga mengatur status dan perlindungan pengungsi dalam Refugee Convention 1951 dan Protokolnya tahun 1967 di mana perbedaan antara pencari suaka dan pengungsi akan dijelaskan pada paragraf selajutnya. Pasal 31 Refugee Convention 1951 mengatur apabila ada pengungsi yang sesuai dengan ketentuan Pasal $1 \mathrm{~A}(2)^{20}$ Konvensi ini, maka Negara Pihak dari Konvensi tidak boleh menjatuhkan hukuman dan wajib menerima pengungsi yang datang walaupun dengan cara ilegal atau bertentangan dengan hukum. ${ }^{21}$ Pasal tersebut juga mencerminkan hukum kebiasaan internasional yang diatur Refugee Convention 1951 dan Protokolnya.

Selain itu, hukum HAM mengakui adanya prinsip non-refoulement. Istilah refoulement berasal dari bahasa Perancis yang berarti refouler yakni untuk

18 Pasal 14 DUHAM menyatakan bahwa :

"(1) Everyone has the right to seek and to enjoy in other countries asylum from persecution.

(2) This right may not be invoked in the case of prosecutions genuinely arising from non-political crimes or from acts contrary to the purposes and principles of the United Nations."

19 Pasal 12 International Covenant on Civil and Political Rights (ICCPR) menyatakan bahwa:

"(2) Everyone shall be free to leave any country, including his own.

(3) The above-mentioned rights shall not be subject to any restrictions except those which are provided by law, are necessary to protect national security, public order (ordre public), public health or morals or the rights and freedoms of others, and are consistent with the other rights recognized in the present Covenant."

Pengungsi yang dimaksud dalam Pasal 1A(2) Refugee Convention 1951 adalah pengungsi yang seseorang yang oleh karena rasa takut yang wajar akan kemungkinan dianiaya berdasarkan ras, agama, kebangsaan, keanggotaan pada suatu kelompok sosial tertentu, atau pandangan politik, berada di luar negeri kebangsaannya, dan tidak bisa atau, karena rasa takut itu, tidak berkehendak berada di dalam perlindungan negeri tersebut.

21 Pasal 31 (1) Refugee Convention 1951 menyatakan: "The Contracting States shall not impose penalties, on account of their illegal entry or presence, on refugee who, coming directly from a territory where their life or freedom was threatened in the sense of article l, enter or are present in their territory without authorization, provided they present themselves without delay to the authorities and show good cause for their illegal entry or presence." 
mengembalikan atau mengusir. ${ }^{22}$ Namun refoulement harus dibedakan dengan pengusiran atau deportasi di mana kedua cara tersebut merupakan cara formal yang kerap dilakukan negara terhadap warga asing yang secara legal berada dinegaranya, namun karena satu dan lain hal diharuskan keluar wiayah negara tersebut. ${ }^{23}$ Prinsip non-refoulement harus dihormati karena berkaitan dengan larangan penyiksaan yang diatur dalam pasal 7 ICCPR serta Pasal 3 CAT yang menyatakan "No State Party shall expel, return ('refouler') or extradite a person to another State where there are substantial grounds for believing that he would be in danger of being subjected to torture". Selain itu, prinsip ini mencerminkan sumber hukum kebiasaan internasional yang menjadi fondasi utama Refugee Convention 1951 dan diatur dalam Pasal 33 (1) yang menyatakan bahwa:

"Prohibition of Expulsion or Return 'states: 'No Contracting State shall expel or return ('refouler') a refugee in any manner whatsoever to the frontiers of territories where his life or freedom would be threatened on account of his race, religion, nationality, membership of a particular social group or political opinion."

Prinsip ini juga diakui telah mendapat status ius cogens dalam Komite Eksekutif UNHCR. ${ }^{24}$

\section{b. Pencari Suaka, Pengungsi, dan Imigran Gelap}

Keseluruhan konsep pencari suaka dan pengungsi serta imigran adalah berkaitan dengan konsep migrasi. Migrasi merupakan suatu bentuk perpindahan seseorang ataupun sekelompok orang dari satu wilayah geografis ke luar perbatasan wilayah negaranya dengan tujuan untuk tinggal di tempat yang bukan wilayah asalnya. ${ }^{25}$ Unsur perpindahan tempat tinggal sangat penting dalam definisi migrasi. Apabila seseorang telah secara resmi pindah tempat, namun terdapat niat sebelumnya untuk kembali ke tempat semula, maka harus dianggap sebagai mobilitas sirkuler, bukan sebagai migrasi. ${ }^{26}$ Orang atau sekelompok orang yang melakukan imigrasi dikenal dengan sebutan 'imigran'. David Coleman menyatakan bahwa "The most commonly used definition of 'immigrant' is a person born outside a given country who has moved to live in that country". ${ }^{27}$

22 Guy S Goodwin-Gill dan Jane McAdam, The Refugee in International Law, New York: Oxford University Press, 2007, hlm. 201.

23 Ibid.

24 UNHCR Executive Committee Conclusion No. 25 (XXXIII-1982), para.b, dikutip dari Alexander Orahkelashvili, Peremptory Norm in International Law, New York: Oxford Monograph in International Law, 2006, hIm. 55

25 International Organization for Migration (IOM), Migrasi Tenaga Kerja dari Indonesia, Jakarta, 2010, hlm. 3. Diakses dari https://www.iom.int/jahia/webdav/shared/shared/mainsite/published docs/Final-LM-ReportBahasa-Indonesia.pdf tanggal 20 November 2016.

26 Ibid.

27 David Coleman, "Immigration, Population and Ethnicity: The UK in International Perspective", Migrant Observatory Briefing: University of Oxford, 2013, hlm. 3. 
Imigran dapat dibagi ke dalam 2 (dua) kategori, yaitu imigran resmi dan imigran ilegal. Imigran resmi melakukan migrasi dengan cara yang sah menurut aturan suatu negara. Berbeda dengan imigran resmi, imigran ilegal melakukan migrasi tanpa mengikuti aturan keimigrasian suatu negara. Terdapat beberapa situasi di mana seseorang dapat disebut sebagai imigran gelap, diantaranya imigran yang masuk secara sembunyi-sembunyi (clandenstein) dengan dokumen palsu, imigran yang menetap lebih dari waktu yang diizinkan (over-stay), dan korban penyelundupan manusia (people smuggling). ${ }^{28}$

Artikel ini tidak hanya fokus pada status pengungsi yang diatur dalam Refugee Convention 1951. Hal ini bertujuan untuk mengantisipasi para pencari suaka yang tidak dapat dikategorikan sebagai pengungsi serta negara-negara yang tidak terikat dengan Refugee Convention 1951. Dengan demikian artikel ini lebih memfokuskan perlindungan pada mereka yang merupakan pencari suaka dikarenakan konflik bersenjata dinegaranya dan terancam persekusi. Namun penting kiranya jika uraian mengenai perbedaan pengungsi dan pencari suaka dijelaskan agar dapat memberikan pemahaman mengenai perbedaan kedua istilah tersebut.

Siapakah pengungsi itu? Pasal IA(2) Refugee Convention 1951 secara tegas menyatakan bahwa pengungsi adalah orang yang memiliki ketakutan akan dipersekusi atas alasan ras, agama, kebangsaan, atau keanggotaan kelompok sosial tertentu atau pendapat politik, berada di luar wilayah negaranya dan tidak dapat dan tidak mampu mendapat perlindungan dari negaranya karena ancaman persekusi tersebut. Namun, 50 tahun kemudian setelah definisi itu berlaku, semakin sedikit orang-orang di luar wilayah negaranya (migran) yang masuk dalam kategori tersebut dan mendapat perlindungan internasional. Terlepas dari beratnya alasan para pencari suaka untuk pergi dari negara mereka, para pencari suaka tersebut tidak diakui sebagai pengungsi berdasarkan Refugee Convention 1951 kecuali situasi yang memotivasi alasan mereka mencari suaka dapat memenuhi definisi dalam Refugee Convention 1951 tersebut.

Misalnya, Pasal IA(2) Refugee Convention 1951 mengkategorikan 'persekusi' sebagai pelanggaran HAM yang dilakukan, didukung atau ditoleransi oleh negara atau 'state like authorities'. Akibatnya, mereka yang dipersekusi oleh entitas bukan negara terkesan tidak masuk dalam definisi ini. Namun, UNHCR telah mendukung berbagai tindakan negara-negara yang perlahan memperluas pengakuan definisi persekusi agar mencakup persekusi yang dilakukan oleh entitas bukan negara. ${ }^{29}$

28 IOM, Op.cit.

29 UNHCR Bureau for Europe, An Overview of Protection Issues in Western Europe: Legislative Trends and Positions Taken by the UNHCR, Geneva: UNHCR, 1995. Beberapa negara termasuk Austria, Belgia, Denmark, Finland, Yunani, Irlandia, Belanda, Spanyol, Protugis, Swedia dan Inggris mendukung pendekatan ini. S. Edminister, "Recklessly Risking Lives: Restrictive Intepretation of "agents of persecution" in Germany and France", US Committee for Refugees, para. 32, http://www.refugees.org/world/articles/wrs99 agentspersecution, diakses 16 November 2016. 
Pendekatan tersebut dilakukan oleh negara-negara berdasarkan pendekatan kemanusiaan yang diatur dalam CAT. Konvensi anti Penyiksaan tersebut merupakan semacam jaring yang mampu menjangkau individu yang tidak mungkin dapat kembali ke negaranya karena risiko akan disiksa seperti yang diatur dalam Pasal 3 CAT yang sudah dijelaskan sebelumnya. Namun permasalahan penggunaan alasan kemanusiaan agar dapat melindungi individu lebih banyak berdasarkan Pasal 3 CAT adalah permasalahan ketergantungan pada kewenangan dan diskresi negara dalam hal penerapannya. Mekanisme perlindungan individu melalui pasal ini menjadi tidak terlalu aman dalam tingkat nasional karena tidak memiliki standar perlakuan yang internasional. ${ }^{30}$

Masalah problematik lain dalam hal pengungsi dalam garis batas yang tipis antara pengungsi dengan migran karena alasan ekonomi (selanjutnya disebut economic migrant). Para migran secara sukarela keluar dari wilayah mereka dengan alasan ekonomi yang lebih baik yang tidak mereka dapatkan dinegaranya. Negaranegara terkadang sulit untuk membedakan mereka yang benar-benar keluar negaranya karena ancaman persekusi atau karena kemiskinan dinegaranya. Layaknya sebagian besar pencari suaka, economic migrant keluar dari negaranya karena alasan kegagalan ekonomi, kondisi politik yang tidak stabil, persekusi, dan kemiskinan. Dengan demikian, baik pengungsi 'asli' maupun 'economic migrant' memiliki motif yang beragam yang membuat mereka keluar dari negaranya yang memicu persekusi.

Dengan demikian, pengkategorian mengenai siapakah yang dapat dikategorikan sebagai 'pengungsi' pada situasi modern saat ini sangatlah sulit. Tentu saja, para positivis akan berpedoman pada pasal 1A(2) Refugee Convention 1951 sebagai dasar hukum penentuan status tersebut. Namun perkembangan situasi migrasi di dunia saat ini mengakibatkan banyaknya migran yang semakin sulit untuk masuk dalam definisi pengungsi dalam Pasal 1A(2) Refugee Convention 1951. Akibatnya, mereka yang tidak masuk kategori tersebut maka tidak akan masuk dalam kategori 'orang yang dilindungi secara internasional'. Padahal menurut Harding, imigran dengan alasan ekonomi pun (economic migrants) juga memiliki alasan persekusi didalamnya. ${ }^{31}$

Kirchner dan Schiano di Pepe mendukung per-nyataan tersebut dengan mengatakan bahwa dewasa ini semakin banyak migran yang masuk dalam kategori 'grey area', 'un-defined', 'unprotected', sehingga menjadi subjek pelanggaran terhadap hak-hak mereka. ${ }^{32} \mathrm{Hal}$ ini juga memperlihatkan bahwa hukum HAM dan

30 Claire Brolan, Op.cit, hlm. 566.

31 J. Harding, The Uninvited: The Refugee at the Richman's Gate, London Review Books, Volume 22, Nomor 3, 3 Januari 2000 diakses dari http://www.Irb.co.uk/v22/n03/jeremy-harding/the-uninvited 20 November 2016

32 A.Kirchnerand L, Schiano Di Pepe, "International Attempts to Conclude a Convention to Combat Illegal Migration", 10 IJRL 673, 1998 dikutip dari Claire Brolan, Op.cit., hlm. 571. 
hukum humaniter internasional tidak selalu mampu untuk menjamin perlindungan terhadap mereka. Dengan demikian, artikel ini tetap menggunakan istilah 'pencari suaka' agar dapat mencakup mereka yang masuk dalam kategori 'grey area' tersebut.

\section{Kejahatan Penyelundupan Manusia}

\section{a. Sumber Hukum}

United Nations Convention against Transnational Organized Crime 2000 yang juga dikenal dengan sebutan Palermo Convention merupakan sebuah instrumen yuridis yang mengatur mengenai kejahatan lintas negara yang terorganisir (transnational organized crime). Di antara kejahatan transnasional terorganisir yang diatur oleh Palermo Convention, diatur pula mengenai kejahatan penyelundupan orang melalui jalur darat, laut, atau udara yang diatur lebih lanjut dalam the Protocol against the Smuggling of Migrants by Land, Sea, and Air (Smuggling Protocol) di tahun 2000. Smuggling Protocol diadopsi tanggal 15 Desember 2000 dan berlaku setelah diratifikasi 45 negara, ${ }^{33}$ yakni pada 28 Januari 2004.

Sebagai tambahan Palermo Convention, ${ }^{34}$ Smuggling Protocol mengatur lebih lengkap mengenai pencegahan dan pemberantasan penyelundupan manusia. ${ }^{35}$ Penerapan atas Protokol ini hanya bagi para negara peserta Protokol, ${ }^{36}$ dan imigran ilegal yang diselundupkan tidak dapat dipidana ${ }^{37}$ oleh negara peserta (negara transit/tujuan) imigran. Setiap negara peserta juga diwajibkan untuk melakukan kriminalisasi atas kejahatan penyelundupan manusia dinegaranya. ${ }^{38}$ Mengingat banyaknya penyelundupan manusia yang menggunakan jalur laut, maka Protokol juga mengatur secara khusus penyelundupan migran melalui laut (smuggling of migrants by sea). Hal tersebut menyangkut kerja sama internasional dengan negara-negara dekat dengan laut perbatasan, ${ }^{39}$ sehingga dibutuhkan pengamanan tambahan di sekitar laut perbatasan. ${ }^{40}$

\section{b. Apakah Penyelundupan Manusia dan Mengapa dikategorikan sebagai Kejahatan? \\ Pasal 3(a) (1) Smuggling Protocol menyatakan bahwa: ${ }^{41}$ \\ "Smuggling of migrants' shall mean the procurement, in order to}

\footnotetext{
33 Bersamaan dengan Smuggling protocol, turut diadopsi pula Protocol to Prevent, Suppress and Punish Trafficking in Persons, Especially Women and Children, Protocol against the Illicit Manufacturing and Trafficking in Firearms, Their Parts and Components and Ammunition Tahun 2000.

34 Pasal 1 Smuggling protocol.

35 Pasal 2 Smuggling protocol.

36 Pasal 4 Smuggling protocol.

37 Pasal 5 Smuggling protocol.

8 Pasal 6 Smuggling protocol.

39 Pasal 7 Smuggling protocol.

Ibid.

41 Pasal 3(a) Smuggling Protocol.
} 
obtain, directly or indirectly, a financial or other material benefit, of the illegal entry of a person into a State Party of which the person is not a national or a permanent resident".

Definisi ilegal dalam tindak kejahatan ini adalah memasuki negara tanpa mematuhi aturan yang disyaratkan negara tersebut. Orang-orang tersebut biasanya tiba ke suatu negara tanpa dokumen sama sekali atau memberikan dokumen palsu yakni dokumen yang dikeluarkan bukan oleh aparat yang berwenang, dikeluarkan dengan cara korupsi, atau digunakan bukan oleh pemegang aslinya. ${ }^{42}$

Penyelundupan manusia dikategorikan sebagai kejahatan jika memenuhi unsur psikis (mens rea) dan unsur tindakan kesalahan (actus reus). Pasal 6 (1) Smuggling Protocol menyatakan bahwa kejahatan penyelundupan manusia harus dilakukan dengan 'niat' untuk mendapatkan keuntungan berupa uang atau materi lain, baik langsung maupun tidak langsung. Sementara itu, tindakan kesalahan yang harus terjadi dalam kejahatan ini diatur dalam Pasal 6 (1) (a) dan (b) dan Pasal 4 Smuggling Protocol. Pasal 6 menyatakan bahwa individu harus terlibat dalam perbuatan fisik nyata dengan menyelundupkan manusia atau membuat dokumen identitas atau dokumen perjalanan yang palsu atau mengadakan, menyediakan atau memiliki dokumen tersebut dengan tujuan memungkinkan terjadinya penyelundupan. Hal lain yang juga penting harus dipenuhi adalah Pasal 4 dan 6 Smuggling Protocol tersebut harus memiliki sifat lintas negara dan melibatkan kelompok kriminal yang teorganisir.

\section{c. Perbedaan Kejahatan Penyelundupan Manusia dengan Perdagangan Manusia}

Kejahatan penyelundupan manusia secara sekilas hampir sama dengan perdagangan manusia (trafficking in persons), padahal kedua istilah tersebut sangat berbeda. Pada tindak penyeludupan manusia, para imigran merupakan objek dari tindak pidana itu sendiri. ${ }^{43}$ Sedangkan perdagangan orang adalah segala tindakan dimulai dari perekrutan, pengiriman, pemindahan, penampungan atau penerimaan seseorang, dengan ancaman atau penggunaan kekerasan, atau bentuk -bentuk pemaksaan lain, penculikan, penipuan, kecurangan, penyalahgunaan kekuasaan atau posisi rentan, memberi atau menerima bayaran atau manfaat memperoleh izin dari orang yang mempunyai wewenang atas orang lain, untuk tujuan eksploitasi. ${ }^{44}$

Dalam hal perdagangan orang, persetujuan diperoleh karena kekerasan, paksaan, penipuan, penculikan, penyekapan, dan lainnya. ${ }^{45}$ Sedangkan dalam hal

42 Pasal 3(b) dan 3(c) (i)-(iii) Smuggling protocol.

43 Pasal 5 Smuggling Protocol.

44 Lihat Pasal 3 huruf (a) Protocol to Prevent Surpress and Punish Trafficiking in Persons, Especially Women and Chrildren.

45 Pasal 1 angka 32 Undang-Undang Nomor 21 tahun 2007 tentang Pemberantasan Tindak Pidana Perdagangan Orang. 
penyelundupan manusia, persetujuan diperoleh karena para pihak memang bermaksud melakukan pemindahan. Dari segi tujuan, perdagangan orang selalu bertujuan untuk melakukan eksploitasi baik seksual maupun prostitusi. Sebaliknya, penyelundupan manusia tujuannya adalah keuntungan dalam pemindahan orang secara ilegal dan tidak secara nyata memberikan implikasi kesewenang-wenangan dan eksploitasi seperti halnya perdagangan manusia. Meskipun pencari suaka lebih condong diselundupkan dari pada diperdagangkan, tidak berarti para pencari suaka jauh dari risiko perdagangan orang karena dalam perjalanan, seringkali pencari suaka tersebut jatuh ke tangan perdagang manusia.

Dengan demikian, Uittenbogaard menyatakan bahwa penyelundupan dan perdagangan dapat saling berhubungan ${ }^{46}$ karena penyelundupan bisa menjadi perdagangan ilegal. Komponen kunci yang membedakan antara penyelundupan dan perdagangan manusia adalah unsur kecurangan, penipuan, atau pemaksaan. Tidak seperti penyelundupan manusia, perdagangan manusia dapat terjadi baik korban dipindahkan di dalam atau di luar negeri sedangkan penyelundupan manusia terjadi secara lintas batas negara.

\section{Perlindungan Pencari Suaka yang Terlibat dalam Kejahatan Penyelundupan Manusia berdasarkan Hukum Internasional}

Tujuan Smuggling Protocol ini secara tegas dinyatakan dalam Pasal 2, yakni: (1) untuk mencegah dan memerangi penyelundupan manusia; (2) untuk memajukan kerjasama negara-negara; dan (3) untuk melindungi hak-hak orang-orang yang diselundupkan. Dengan demikian, menghukum atau mengkriminalisasi orang yang diselundupkan bukan merupakan tujuan dari Protokol, bahkan mereka menjadi objek perlindungan dari Protokol. Caranya adalah dengan mendorong negaranegara untuk membuat undang-undang dan langkah hukum lain untuk melindungi orang yang diselundupkan dalam situasi di mana tindak pidana penyelundupan akan atau telah membahayakan jiwa dan keamanan orang-orang tersebut. Hal ini termasuk jika tindakan penyelundupan tersebut telah di luar batas kemanusiaan, misalnya terjadi pemerkosaan, perbudakan, hingga eksploitasi orang-orang yang diselundupkan tersebut. ${ }^{47}$ Pasal 16 dari Protokol telah secara rinci mengatur mengenai langkah-langkah perlindungan dan bantuan terhadap mereka yang menjadi objek penyelundupan manusia tersebut. ${ }^{48}$

46 Interview with Alet Uittenbogaard, representative of the Dutch national police, and a detective on the renowned 'Dover Case', The Hague, the Netherlands, 4 July 2001 dikutip dari Claire Brolan, Op.cit., hlm. 571.

47 Pasal 6(3) (a) dan (b) Smuggling protocol.

48 Pasal 16Smuggling protocol:

Protection and assistance measures

1. In implementing this Protocol, each State Party shall take, consistent with its obligations under international law, all appropriate measures, including legislation if necessary, to preserve and protect the rights of persons who have been the object of conduct set forth in article 6 of this Protocol as accorded under applicable 
Namun, permasalahan dari penulisan ini adalah ketika orang-orang yang diselundupkan adalah pencari suaka dan mereka menggunakan jasa penyelundup untuk pindah ke negara lain karena ancaman persekusi. Alasan mereka untuk tidak menggunakan jalur yang formal untuk mencari suaka adalah karena pada kenyataannya tidak ada lagi langkah hukum yang praktis bagi seseorang untuk meninggalkan negara mereka dan masuk ke negara lain. Intinya, penyelundupan manusia adalah kerap menjadi satu-satunya cara bagi orang-orang yang sudah frustasi untuk menyelamatkan jiwa mereka.

Sayangnya, tindakan penyelundupan manusia yang kerap dipilih pencari suaka tersebut, sejak Palermo Convention dan Smuggling Protoco/ berlaku, telah menjadi tindak pidana yang dilarang. Palermo Convention dan Smuggling Protocol bukan instrumen HAM internasional per se namun hanya sebuah peraturan dalam perjanjian internasional yang membantu menggalang kerja sama negara dalam membasmi kejahatan transnasional yang terorganisir. Namun, jika salah satu fungsi dari Protokol adalah untuk melindungi hak-hak orang yang diselundupkan maka Protokol juga harus secara tegas menyetujui perlindungan hak-hak pencari suaka.

Sebagai contoh adalah kasus pengungsi Rohingya, mereka memilih untuk pergi ke Thailand, sebagai pintu masuk ke negara-negara lain seperti Malaysia dan Indonesia, dikarenakan konflik antara kelompok Budha dan Muslim di sana. ${ }^{49}$ Cara formal tidak mungkin mereka tempuh karena mereka bahkan tidak diakui sebagai warga negara Myanmar. Pengungsi Rohingya memilih membayar penyelundup karena terancam persekusi diwilayahnya dan cara ini merupakan cara alternatif yang paling masuk akal dibanding cara formal yang penuh birokrasi, lama, dan membahayakan hidup mereka. Bagi para pencari suaka, kemungkinan untuk bisa hidup tanpa rasa takut dan ancaman persekusi adalah tujuan yang akan mereka dapatkan bagaimanapun caranya termasuk dengan penyelundupan manusia.

international law, in particular the right to life and the right not to be subjected to torture or other cruel, inhuman or degrading treatment or punishment.

2. Each State Party shall take appropriate measures to afford migrants appropriate protection against violence that may be inflicted upon them, whether by individuals or groups, by reason of being the object of conduct set forth in article 6 of this Protocol.

3. Each State Party shall afford appropriate assistance to migrants whose lives or safety are endangered by reason of being the object of conduct set forth in article 6 of this Protocol.

4. In applying the provisions of this article, States Parties shall take into account the special needs of women and children.

5. In the case of the detention of a person who has been the object of conduct set forth in article 6 of this Protocol, each State Party shall comply with its obligations under the Vienna Convention on Consular Relations, where applicable, including that of informing the person concerned without delay about the provisions concerning notification to and communication with consular officers. https://www.arrahmah.com/news/2016/10/29/menjadi-korban-perdagangan-manusia-5-muslim-rohingyakini-malah-dipenjara-di-myanmar.html, diakses 26 November 2016. 
Dengan demikian, perlu dianalisa aturan-aturan dalam Smuggling Protocol apakah sudah mampu memberikan perlindungan kepada para pencari suaka yang menggunakan cara penyelundupan manusia untuk bisa masuk ke negara lain. Pasal 19Smuggling Protocol menyatakan bahwa:

"Nothing in this Protocol shall affect the other rights, obligations and responsibilities of States and individuals under international law, including international humanitarian law and international human rights law and, in particular, where applicable, the 1951 Convention and the 1967 Protocol relating to the Status of Refugees and the principle of non-refoulement as contained therein."

Pasal di atas secara tegas menyatakan bahwa Protokol ini tetap menghormati kewajiban negara yang tertuang baik dalam hukum HAM maupun hukum Humaniter Internasional termasuk prinsip non-refoulement sekalipun negara tersebut bukan merupakan negara pihak dari Refugee Convention 1951 dan Protokol 1967.

Seperti telah dijelaskan pada bab sebelumnya, tidak semua pencari suaka adalah pengungsi dan mendapat keistimewaan berdasarkan Refugee Convention 1951. Namun, pencari suaka tetap dilindungi oleh hukum HAM yang lebih umum yakni prinsip non-refoulment, yang juga merupakan fondasi utama dari Refugee Convention 1951. Prinsip ini sudah diakui sebagai norma ius cogens yakni norma tertinggi dalam hukum internasional di mana tidak boleh disimpangi oleh norma lain dibawahnya. ${ }^{50}$ Dengan kata lain, meskipun para pencari suaka tersebut masuk ke dalam suatu negara secara ilegal, proses penegakan hukum terhadap mereka atas masuk tanpa izin ke dalam suatu negara tidak boleh membahayakan hak mereka meminta suaka karena persekusi dengan cara mengembalikan mereka ke negaranya. Dengan demikian, terlepas apakah negara tersebut negara pihak Refugee Convention 1951 atau bukan, negara tersebut dilarang untuk mengembalikan orang tersebut ke negara di mana hidup dan kebebasan mereka terancam.

Namun apakah penyelundupan manusia yang merupakan pencari suaka tidak dapat dikatakan melanggar hukum? Dapatkah penyelundupan manusia yang merupakan tindak pidana ketika digunakan oleh orang untuk mencari suaka karena persekusi menjadi bukan sebuah 'tindak pidana'? Pasal 4 dan 6 dari Smuggling protocol secara jelas menyatakan bahwa penyelundupan manusia adalah tindak pidana dan mengharuskan tindakan investigasi, penahanan, dan penututan terhadap para penyelundup. Namun, apakah fakta bahwa penyelundupan

50 Pasal 53 Vienna Convention on the Law of Treaties 1969 (VCLT) menyatakan bahwa: "A treaty is void if, at the time of its conclusion, it conflicts with a peremptory norm of general international law. For the purposes of the present Convention, a peremptory norm of general international law is a norm accepted and recognized by the international community of States as a whole as a norm from which no derogation is permitted and which can be modified only by a subsequent norm of general international law having the same character." 
mengetahui bahwa orang-orang yang mereka selundupkan adalah pencari suaka yang terancam persekusi dinegaranya dapat meringankan hukuman mereka? Protokol belum sejauh itu membahasnya.

Hal lain yang harus diperhatikan adalah Pasal 7 Smuggling Protocol yangmenyatakan bahwa: "States Parties shall cooperate to the fullest extent possible to prevent and suppress the smuggling of migrants by sea, in accordance with the international law of the sea."

Pasal di atas memperlihatkan bahwa negara harus bekerja sama untuk mencegah dan menghentikan penyelundupan manusia lewat laut. Meskipun tindakan tersebut tetap harus mematuhi hukum internasional yang berlaku, namun bagaimana jika dalam praktiknya ternyata kapal tersebut berisi pencari suaka di mana pengungsi tersebut membayar sejumlah uang kepada seseorang dengan harapan mereka dapat dibawa ke negara yang akan memberikan suaka, apakah tindakan seperti itu harus dicegah dan dihentikan ${ }^{51}$ Jika hal ini dilakukan, maka negara tersebut dapat berpotensi melanggar prinsip non-refoulement yang sudah dijelaskan di atas. Dengan demikian, implementasi Pasal ini juga harus memperhatikan Pasal 9(1) (a) Smuggling Protocol menyatakan:

"1. Where a State Party takes measures against a vessel in accordance with article 8 of this Protocol, it shall:

(a) Ensure the safety and humane treatment of the persons on board..."

Pasal di atas merupakan pasal pengaman bagi tindakan negara yang akan menindak kapal yang menyelundupkan manusia. Pasal ini juga kembali secara implisit menjamin prinsip non-reofulement. Artinya, mengembalikan para pencari suaka kenegaranya bukanlah tindakan yang menjamin keamanan dan perlakuan manusiawi dari orang-orang yang di dalam kapal.

Selanjutnya, Pasal 15 (1) Smuggling Protocol mengajak semua negara untuk menerapkan program pemberian informasi untuk meningkatkan kesadaran mengenai fakta bahwa "penyelundupan manusia adalah tindakan kriminal.....dan bisa menimbulkan resiko berbahaya kepada migran yang diselundupkan". Para pencari suaka, meskipun bukan penyelundup, namun kerap menggunakan jasa penyelundup untuk membantu tujuan mereka. Pasal ini menjadi penting bagi negara khususnya petugas imigrasi untuk juga menyadarkan mereka bahwa di antara para migran yang diselundupkan juga terdapat mereka yang terancam persekusi dinegaranya dan tidak punya pilihan lain selain menggunakan kegiatan penyelundupan manusia untuk menyelamatkan jiwanya. Hal ini sesuai dengan Pasal 14 (1) (e) yang menyatakan bahwa:

51 Canadian Refugee Council, "Migrant Smuggling and Trafficking in Persons”, http://ccrweb.ca/sites/ccrweb.ca/ files/static-files/traffick.html, diakses 20 November 2016. 
"States Parties shall cooperate with each other and with competent international organizations, non-governmental organizations, other relevant organizations and other elements of civil society as appropriate to ensure that there is adequate personnel training in their territories to prevent, combat and eradicate the conduct set forth in article 6 of this Protocol and to protect the rights of migrants who have been the object of such conduct. Such training shall include:...The humane treatment of migrants and the protection of their rights as set forth in this Protocol."

Dengan demikian, negara pihak Smuggling Protocol harus dapat melakukan harmonisasi peraturan nasionalnya agar di satu sisi dapat mendukung kerjasama internasional untuk menghapuskan kejahatan penyelundupan manusia, namun di sisi lain dapat terus memberikan perlindungan kepada para pencari suaka yang terancam persekusi. Peraturan yang lengkap dan proporsional menjadikan negara terhindar dari pelanggaran kewajiban internasionalnya berdasarkan HAM namun di sisi lain tetap memperlihatkan taringnya agar tidak dijadikan negara yang paling disukai oleh para penyelundup manusia.

\section{Penutup}

Berdasarkan analisa tentang permasalahan kejahatan penyelundupan manusia dalam hubungannya dengan perlindungan etnis Rohingya sebagai pencari suaka dalam hukum internasional, maka dapat disimpulkan bahwa kejahatan penyelundupan manusia sudah menjadi keprihatinan masyarakat internasional, selain merupakan kejahatan transnasional, namun juga merugikan negara-negara serta membahayakan jiwa manusia. Itulah yang menjadi alasan lahirnya Protokol khusus tentang Penyelundupan Manusia yang dikenal dengan Smuggling Protocol. Namun demikian, masyarakat internasional juga tidak boleh mengenyampingkan fenomena para pencari suaka yang pergi dari negaranya karena ancaman persekusi dan terpaksa masuk ke negara lain secara ilegal seperti pengungsi Rohingya.

Para pencari suaka tersebut juga dilindungi dalam hukum internasional khususnya hukum HAM. Baik pengungsi ataupun economic migrant adalah tetap pencari suaka, meskipun memiliki motif yang berbeda untuk bermigrasi ke negara lain, namun motif tersebut seringkali sama-sama berujung pada persekusi. Meskipun penyelundupan manusia adalah tindak pidana, tindakan tersebut seringkali dipilih para pencari suaka karena tidak ada jalan lain untuk menyelamatkan hidup mereka. Dengan demikian, guna memberikan perlindungan kepada para pencari suaka, hal yang harus dicamkan adalah tujuan Smuggling Protocol bukan untuk memidana pencari suaka sehingga pasal-pasal pengaman dalam Protokol ini lahir guna melindungi mereka. 
Di samping itu, Smuggling Protocol juga mendorong negara pihak untuk memberikan pendidikan kepada para pejabatnya khususnya imigrasi untuk melindungi dan menghormati hak para pencari suaka khususnya prinsip nonrefoulement.

\section{Daftar Pustaka}

\section{Buku}

Goodwin-Gill, Guy S. dan Jane McAdam, The Refugee in International Law, Oxford University Press, New York, 2007.

Harding, J., the Uninvited: The Refugee at the Richman's Gate, Profile Books, London, 2000.

Orakhelashvili, Alexander, Peremptory Norm in International Law, Oxford Monograph in International Law, New York, 2006.

\section{Dokumen Lain}

Ameera, "Menjadi Korban Perdagangan Manusia, 5 Muslim Rohingya kini Malah Dipenjara di Myanmar", https://www.arrahmah.com/news/2016/10/29/ Menjadi-Korban-Perdagangan-Manusia-5-Muslim-Rohingya-Kini-MalahDipenjara-Di-Myanmar.html, diakses 26 November 2016.

Bidinger (et.al), Sarah, "Protecting Syrian Refugees: Laws, Policies, and Global Responsibility Sharing", Boston University Report, 2014.

Brolan, Claire, "An Analysis of the Human Smuggling Trade and the Protocol against the Smuggling of Migrants by Land, Air and Sea (2000) from a Refugee Protection Perspective", International Journal of Refugee Law, Vol. 1, No. 4, October 2002.

Canadian Refugee Council, "Migrant Smuggling and Trafficking in Persons", http://ccrweb.ca/sites/ccrweb.ca/files/static-files/traffick.html, diakses tanggal 10 November 2016.

Coleman, David, "Immigration, Population and Ethnicity: The UK in International Perspective", Migrant Observatory Briefing: University of Oxford, 2013.

DW, UNHCR in Bangladesh accuses Myanmar troops of Killing, Eape, Arson in Rohingnya Communities, http://www.dw.com/en/unhcr-in-bangladeshaccuses-myanmar-troops-of-killings-rape-arson-in-rohingya-communities/a36515500, diakses 26 November 2016.

Edminister, S., "Recklessly Risking Lives: Restrictive Interpretation of "against of persecution" in Germany and France', Committee for Refugees, para.32, http://www.refugees.org/world/articles/wrs99 agentspersecution

Kent, Andrew, "Evaluating The Palestinians Claimed Right of Return", University of 
Pennsylvania Journal of International Law, Vol. 34, 2012.

Kirchnerand L, A. dan Schiano DiPepe, 'International Attempts to Conclude a Convention to Combat Illegal Migration' 10 IJRL 673.

Penelope, Matthew, dan Harley Tristan, "Refugees Protection and Regional Cooperation in South East Asia, A Fieldwork Research", Australian National University, 2014.

UNHCR, "Burma: Study: Rohingya among World's Most Persecuted," UNHCR

Refugee Daily, October 20, 2014, http://www.unhcr.org/cgibin/texis/vtx/ refdaily?pass $=52 \mathrm{fc} 6 \mathrm{fbd} 5 \& \mathrm{id}=5445 \mathrm{f0238}$, diakses 10 November 2016. "Figures at Glance", http://www.unhcr.org/figures-at-a-glance.html, diakses 10 November 2016.

, "States of denial A review of UNHCR's response to the protracted situation of stateless Rohingya refugees in Bangladesh", http://www.unhcr.org/enus/research/evalreports/4ee754c19/states-denial-review-unhcrs-responseprotracted-situation-stateless-rohingya.html, diakses 26 November 2016.

\section{Dokumen Hukum}

Deklarasi Universal Hak Asasi Manusia.

United Nations Convention Against Transnational Organized Crime 2000 (Palermo Convention).

Protocol Against The Smuggling Of Migrants By Land, Sea And Air, Supplementing

The United Nations Convention Against Transnational Organized Crime 2000.

Internasional Covenant on Civil and Poltical Rights (ICCPR).

Convention against Torture and Other Cruel Inhuman and Degrading Treatment or Punishment (CAT).

Convention Relating to the Status of Refugees 1951. 